\title{
Meeting of the Standing Commission of the Red Cross and Red Crescent
}

The Standing Commission of the Red Cross and Red Crescent met on 8 April 1987 in Geneva; its new composition is as follows:

Chairman: Dr. A. Abu Goura (Jordan);

Vice-Chairman: Botho Prince of Sayn-Wittgenstein-Hohenstein (Federal Republic of Germany);

Other elected members: Dr. A. Hantos (Hungary);

Mrs M. Harmon (Brazil);

Mr. B. M. Hove (Zimbabwe).

The ICRC was represented first by Mr. A. Hay, President, then by Mr. M. Aubert, Vice-President, and by Mr. J. Moreillon, Director General. Mr. C. Sommaruga, President elect, attended part of the meeting.

The League was represented by Mr. E. de la Mata, President, and by Mr. H. Høegh, Secretary General, replacing General R. Espino who was unable to attend.

The nine members of the Commission examined the various points on the agenda, some of which merited in-depth consideration.

The Standing Commission agreed to place the revision of the regulations on the use of the emblem on the agenda for the next meeting of the Council of Delegates. It also adapted its own regulations to the new Statutes of the Movement and drew up the provisional agenda for the Council of Delegates to be held in Rio de Janeiro in November 1987.

The Commission examined the nominations for the award of the Henry Dunant Medal and selected the following people: Mr. J.-J. Vega Aguiar whose candidature had been submitted by the Cuban Red Cross, and Mrs. M. J. Burnier who had been proposed by the ICRC. Three medals were awarded to people who have given distinguished service to the International Red Cross; the first two had also been engaged in activities in the field: Mr. K. Warras, Finnish Red Cross, Dr. A. Schlögel, German Red Cross in the Federal Republic of Germany, and Princess Gina of Liechtenstein. A sixth medal was awarded posthumously to Mr. O. Niskanen, a 
former Secretary-General of the Ethiopian Red Cross; he was of Swedish origin and his candidature had been put forward by the Ethiopian Red Cross Society.

The Commission also considered the follow-up to be given to the Twenty-fifth International Conference of the Red Cross; at its next session it will continue its discussions on the Twenty-sixth International Conference planned to take place in Colombia and, in particular, it should decide on the date.

Finally, both the representatives from the League and those from the ICRC informed the members of the Commission about the respective activities of the two institutions and those jointly conducted by them.

On behalf of the members of the Commission, Dr. Abu Goura warmly thanked Mr. Hay, who was representing the ICRC there for the last time, for everything he had contributed to the Commission's work.

The Commission will meet again in Rio de Janeiro in November 1987. 